\title{
Arachidonic acid epoxygenase and 12(S)- lipoxygenase: evidence of their concerted involvement in ductus arteriosus constriction to oxygen
}

\author{
Barbara Baragatti and Flavio Coceani
}

\begin{abstract}
Oxygen promotes closure of the ductus arteriosus at birth. We have previously presented a scheme for oxygen action with a cytochrome P450 (CYP450) hemoprotein and endothelin-1 (ET-1) being, respectively, sensor and effector, and a hypothetical monooxygenase product serving as a coupling link. We have also found in the vessel arachidonic acid (AA) 12 $(S)$-lipoxygenase (12-lipoxygenase) undergoing upregulation at birth. Here, we examined the feasibility of a sensor-to-effector messenger originating from AA monooxygenase and 12-lipoxygenase pathways. The epoxygenase inhibitor, $N$-methylsulfonyl6-(2-)hexanamide, suppressed the tonic contraction of ductus to oxygen. A similar effect was obtained with 12-lipoxygenase inhibitors baicalein and PD 146176. By contrast, none of the inhibitors modified the endothelin-1 contraction. Furthermore, an AA $\omega$-hydroxylation product, 20-hydroxyeicosatetraenoic acid (20-HETE), reportedly responsible for oxygen contraction in the systemic microvasculature, had no such effect on the ductus. We conclude that AA epoxygenase and 12-lipoxygenase jointly produce a hitherto uncharacterized compound acting as oxygen messenger in the ductus.
\end{abstract}

Key words: ductus arteriosus, oxygen sensing, arachidonic acid epoxygenase, arachidonic acid lipoxygenase, arachidonic acid $\omega$-hydroxylation, 20-hydroxyeicosatetraenoic acid, endothelin, fetal and neonatal physiology.

Résumé : L'oxygène favorise la fermeture du canal artériel à la naissance. Nous avons présenté antérieurement un mécanisme d'action de l'oxygène dans lequel une hémoprotéine, le cytochrome P450 (CYP450), et l'endothéline-1 (ET-1) sont respectivement capteur et effecteur, et dans lequel un produit hypothétique de la monooxygénase agit comme agent de couplage. Nous avons aussi noté une augmentation de l'arachidonate (AA) 12(S)-lipoxygénase (12-lipoxygenase) dans les vaisseaux à la naissance. Dans la présente étude, nous avons examiné la possibilité qu'un messager capteur-effecteur émane des voies de l'AA monooxygénase et de l'AA 12-lipoxygénase. L'inhibiteur de l'époxygénase, MS-PPOH, a supprimé la contraction tonique du canal induite par l'oxygène. Un effet similaire a été obtenu avec les inhibiteurs de la 12-lipoxygénase, baicaléine et PD 146176. Toutefois, aucun des inhibiteurs n'a modifié la contraction induite par l'ET-1. De plus, un produit de l' $\omega$-hydroxylation de l'AA, l'acide 20-hydroxyéicosatétraénoïque (20-HETE), qui serait à l'origine de la contraction provoquée par l'oxygène dans le système microvasculaire, n'a pas eu d'effet de ce genre sur le canal. Nous concluons que l'AA époxygénase et l'AA 12-lipoxygénase coproduisent une substance, non caractérisée à ce jour, qui agit comme messager de l'oxygène dans le canal.

Mots-clés : canal artériel, capteur d'oxygène, acide arachidonique époxygénase, acide arachidonique lipoxygénase, $\omega$-hydroxylation de l'acide arachidonique, acide 20- hydroxyéicosatétraénoïque, endothéline, physiologie fœetale et néonatale.

[Traduit par la Rédaction]

Received 21 January 2011. Accepted 21 April 2011. Published at www.nrcresearchpress.com/cjpp on 27 May 2011.

Abbreviations: 20-HETE, 20-hydroxyeicosatetraenoic acid; AA, arachidonic acid; CYP450, cytochrome P450; EET, epoxyeicosatrienoic acid; ET-1, endothelin-1; MS-PPOH, $\mathrm{N}$ methylsulfonyl-6-(2-)hexanamide; PG, prostaglandin; $\mathrm{TXA}_{2}$, thromboxane $\mathrm{A}_{2}$; WT, wild type.

B. Baragatti. Scuola Superiore Sant'Anna e Istituto di Fisiologia Clinica, Consiglio Nazionale delle Ricerche, 56100 Pisa, Italy. F. Coceani. Scuola Superiore Sant'Anna e Istituto di Fisiologia Clinica, Consiglio Nazionale delle Ricerche, 56100 Pisa, Italy; Scuola Superiore Sant'Anna, Piazza Martiri della Libertà 33, 56127 Pisa, Italy.

Corresponding author: Flavio Coceani (e-mail: coceani@sssup. it).

\section{Introduction}

The ductus arteriosus is a fetal shunt, connecting the pulmonary artery with the aorta, that closes shortly after birth coincidentally with the natural rise in blood oxygen tension. Our previous studies have identified a cytochrome P450 (P450) hemoprotein of the 3A subfamily, specifically CYP3A13 in the mouse, as the prime oxygen sensor within ductal muscle and endothelin-1 (ET-1) as the ultimate effector for the contraction (Coceani 1999; Coceani et al. 1999; Coceani and Kelsey 2000; Baragatti et al. 2011). Still undefined, however, is the nature of the functional linkage between sensor and effector, although much evidence points to a CYP450-based monooxygenase reaction as the source of the putative messenger (Coceani et al. 1988; Coceani 1999). Knowing the importance of the eicosanoid system in the control of blood vessels, the ductus included (Smith 1998), we 
have attempted in the past to link the oxygen contraction of the ductus to an arachidonic acid (AA) epoxide (i.e., epoxyeicosatrienoic acid (EET)) but results have been negative (Coceani et al. 1988). Lately, however, this system has acquired a greater degree of complexity with the characterization of a host of vasoactive agents, originating through epoxygenaseand lipoxygenase-based reactions (Pace-Asciak et al. 1999; Chen et al. 2008; Chawengsub et al. 2009), and the realization of the potential for synthesis still being unfulfilled. Furthermore, a product of AA w-hydroxylation, 20hydroxyeicosatetraenoic acid (20-HETE), has been implicated in oxygen sensing of the systemic microvasculature (Kunert et al. 2001).

Application of this new knowledge to the mechanism of ductus closure has been limited or inconclusive. 20-HETE is seemingly not found in the ductus despite the presence of an appropriate CYP450 hemoprotein for its synthesis (Baragatti et al. 2009). Conversely, there is an active 12-lipoxygenase pathway, conceivably located in the muscle, whose function needs to be determined (Baragatti et al. 2009). Significantly, its initial enzyme, that is, 12/15-lipoxygenase (encoded by Alox 15) ${ }^{1}$, is markedly upregulated in the neonatal ductus (Costa et al. 2006), as one would expect from any factor linked to the process of closure.

From this premise, the objective of the present study in the mouse ductus was twofold: ( $i$ ) to assess the possible involvement of AA epoxygenase and 12-lipoxygenase in the oxygen activation sequence and (ii) to examine whether 20-HETE accords in its action with a role as oxygen mediator.

\section{Materials and methods}

\section{Animals}

Experiments were carried out with wild-type (WT) C57BL/6 mice (Harlan, San Pietro al Natisone, Italy) (litter size 1-12) and, in a few cases, with Cyp3a $a^{-1-}$ mice of the FVB strain (litter size 8-10) (courtesy of Dr. A.H. Schinkel; see van Herwaarden et al. 2007). In a previous study, it has been shown that the mutant lacks a critical isoform (i.e., CYP3A13) for oxygen sensing in the ductus (Baragatti et al. 2011). In addition, it has been confirmed that WT C57BL/6 and WT FVB strains share a similar response to oxygen in their fetal duct (Baragatti et al. 2011). Animals were housed in temperature- and humidity-controlled quarters, with constant $12 \mathrm{~h}$ light : $12 \mathrm{~h}$ dark cycles, and were given food and water ad libitum. Surgical procedures and experimental protocols were approved by the Animal Care Committee of the Ministry of Health (Rome, Italy).

\section{Solutions and drugs}

The Krebs medium had the following composition: 118 $\mathrm{mol} / \mathrm{L} \mathrm{NaCl}, 4.7 \mathrm{~mol} / \mathrm{L} \mathrm{KCl}, 2.5 \mathrm{~mol} / \mathrm{L} \mathrm{CaCl} 2,1 \mathrm{~mol} / \mathrm{L}$ $\mathrm{KH}_{2} \mathrm{PO}_{4}, 0.9 \mathrm{~mol} / \mathrm{L} \mathrm{MgSO}_{4}, 11.1 \mathrm{~mol} / \mathrm{L}$ dextrose, and 25 $\mathrm{mol} / \mathrm{L} \mathrm{NaHCO}_{3}$. Solutions were bubbled with gas mixtures containing either no $\mathrm{O}_{2}$ or $\mathrm{O}_{2}$ in various concentrations $\left(2.5 \%, 12.5 \%, 30 \%\right.$, and $95 \%$ ), plus $5 \% \mathrm{CO}_{2}$ and balance $\mathrm{N}_{2}$, with the intent of duplicating the fetal $\left(2.5 \% \mathrm{O}_{2}\right)$ and neonatal (from $12.5 \% \mathrm{O}_{2}$ upwards) conditions. For maximal contraction, oxygen is required at concentrations exceeding the physiological range (Coceani et al. 1999), since a steep tissue gradient may occur even with a small-size vessel (Fay 1973). $\mathrm{PO}_{2}$ of the medium was measured with a Chiron gas analyzer (model 248, Chiron Diagnostics,Halstead, UK) and was $0.84 \pm 0.01 \mathrm{kPa}(n=41), 2.15 \pm 0.01 \mathrm{kPa}(n=41), 6.33 \pm$ $0.19 \mathrm{kPa}(n=21), 20.7 \pm 0.2 \mathrm{kPa}(n=21)$, and $82.5 \pm 0.1$ $\mathrm{kPa}(n=21)(\mathrm{pH} 7.410 \pm 0.005 ; n=41)$ with $0 \%, 2.5 \%$, $12.5 \%, 30 \%$, and $95 \% \mathrm{O}_{2}$ mixtures, respectively.

The following compounds were used: the suicide-substrate inhibitor of AA epoxidation, $N$-methylsulfonyl-6-(2-)hexanamide (MS-PPOH, courtesy of Dr. M. Schwartzman) (Wang et al. 1998); the 12-lipoxygenase inhibitor baicalein (SigmaAldrich, St. Louis, Mo., USA), with a confirmed selective action in the ductus arteriosus (Baragatti et al. 2009); the 12/ 15-lipoxygenase inhibitor, 6,11-dihydro-5-thia-11-aza-benzo [a]-fluorene (PD 146176) (Sendobry et al. 1997; DeCostanzo et al. 2010); 20-HETE (Cayman Chemical, Ann Arbor, Mich., USA); the thromboxane $\mathrm{A}_{2}\left(\mathrm{TXA}_{2}\right)$ analog 9,11-epithio-11,12-methano-TXA 2 (ONO-11113; courtesy of ONO Pharmaceutical, Osaka, Japan); the prostaglandin (PG) endoperoxide analog and $\mathrm{TXA}_{2}$ mimic $9 \alpha, 11 \alpha$-epoxy-methano-15hydroxy-prosta-5,13-dienoic acid (U-44069; Cayman Chemical); and endothelin-1 (ET-1; human-porcine type; Peninsula Laboratories, San Carlos, Calif., USA). Concentrations of the inhibitors were derived from the literature with the aim of combining efficacy with selectivity.

ONO-11113 and U-44069 were dissolved in distilled ethanol (respectively 5 and $0.1 \mathrm{mg} / \mathrm{mL}$ ), and aliquots (stored at $-70{ }^{\circ} \mathrm{C}$ ) were diluted, respectively, with Tris buffer ( $\mathrm{pH}$ 7.4) and saline. MS-PPOH, baicalein, and PD 146176 were also dissolved in ethanol (respectively 16.15, 1.35, and $2.37 \mathrm{mg} / \mathrm{mL}$ ) before the final solution was prepared in Krebs medium. 20-HETE was first dissolved in ethanol $(0.1 \mathrm{mg} / \mathrm{mL})$, and then an appropriate aliquot was evaporated to near dryness under a stream of $\mathrm{N}_{2}$ before being reacted with a stoichiometric amount of $\mathrm{Na}_{2} \mathrm{CO}_{3}$; the resulting product was prepared as a $100 \mu \mathrm{mol} / \mathrm{L}$ stock in Tris buffer $(\mathrm{pH} 9.0)$ to be ultimately diluted with Krebs medium as required. ET-1 was dissolved in sterile water with $0.05 \%$ human serum albumin $(100 \mu \mathrm{mol} / \mathrm{L})$, and aliquots of this stock solution were stored at $-20{ }^{\circ} \mathrm{C}$ until use. Ethanol concentration in fluid bathing the ductus preparations did not exceed $0.01 \%$ (MS-PPOH), $0.2 \%$ (baicalein), $0.01 \%$ (PD 146176), $0.001 \%$ (ONO-11113), or $0.1 \%$ (U-44069). Ethanol vehicle has no significant effect at the given concentrations (Reese et al. 2009), and this was confirmed here. Solutions of baicalein were protected from light.

Concentrations of compounds are given in molar units and refer to their final value in Krebs medium.

\section{In vitro recording}

Term fetal mice, both WT and Cyp $3 a^{-1-}$ (gestational age 19 days), were delivered by cesarean section under halothane anesthesia and were killed by cervical dislocation. Body weight was $0.8-1.5$ and 1.0-1.3 g, respectively, for WT and mutant, and only 1 fetus was used in each experiment. Procedures for ductus dissection, normalization of internal circumference, and mechanical record have been described (Coceani et al. 1999). Briefly, the animal was secured with its left side

${ }^{1} 12 / 15$-lipoxygenase manifests predominantly 12-lipoxygenase activity in rodents (Johannesson et al. 2010). 
Fig. 1. Differential effect of arachidonic acid epoxygenase and 12-lipoxygenase inhibitors on the oxygen- versus ET-1-induced contraction in the isolated mouse ductus arteriosus. $(a, c)$ Concentration-response curves to oxygen before (open circle; $n=6)$ and during treatment with $(a)$ MS-PPOH $(5 \mu \mathrm{mol} / \mathrm{L})($ closed circle; $n=4)$ and $(c)$ baicalein $(10 \mu \mathrm{mol} / \mathrm{L})($ closed circle; $n=4)$ or PD $146176(1 \mu \mathrm{mol} / \mathrm{L})(\mathrm{half}-\mathrm{filled}$ circle; $n=4)$. $(b, d)$ Concentration-response curves to ET-1 before (open circle; $n=6)$ and during treatment with $(b) \mathrm{MS}-\mathrm{PPOH}(5 \mu \mathrm{mol} / \mathrm{L})(\mathrm{closed}$ circle; $n=4)$ and $(d)$ baicalein $(10 \mu \mathrm{mol} / \mathrm{L})$ (closed circle; $n=4)$.,$p<0.01$ relative to control. Note that control curves for oxygen and ET1 were obtained concomitantly with another study (Baragatti et al. 2011) and are presented here again with one more experiment added to each group. In this and the following figure, certain values are defined by one- rather than two-way error bars for better clarity. ET-1, endothelin-1; MS-PPOH, $N$-methylsulfonyl-6-(2-)hexanamide.
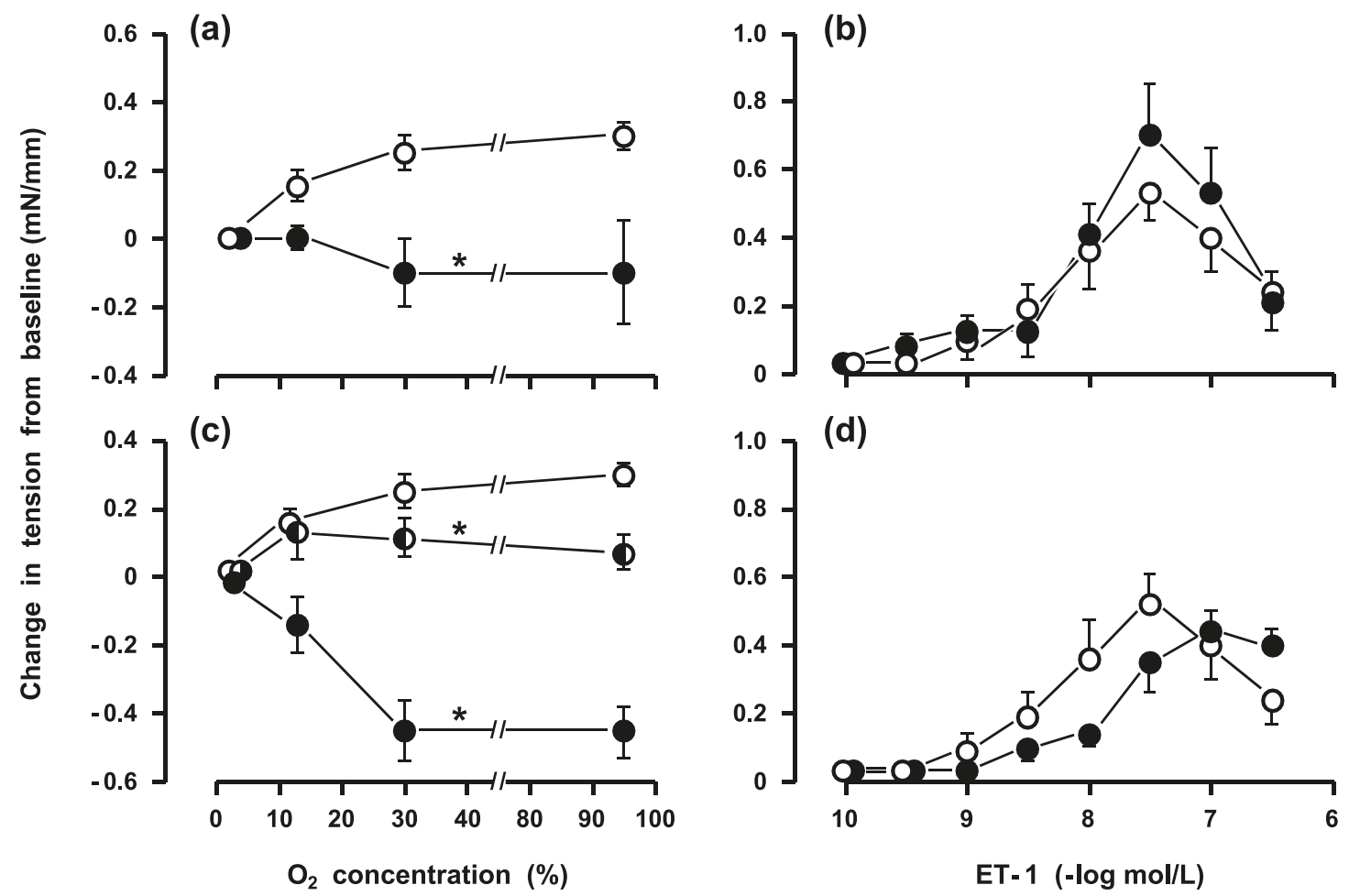

Fig. 2. Effect of 20-hydroxyeicosatetraenoic acid (20-HETE) on the isolated mouse ductus arteriosus. Concentration-response curve in wild-type (WT; open circle) and Cyp $3 a^{-/-}$mutant (closed circle) ( $n=3$ for both groups).

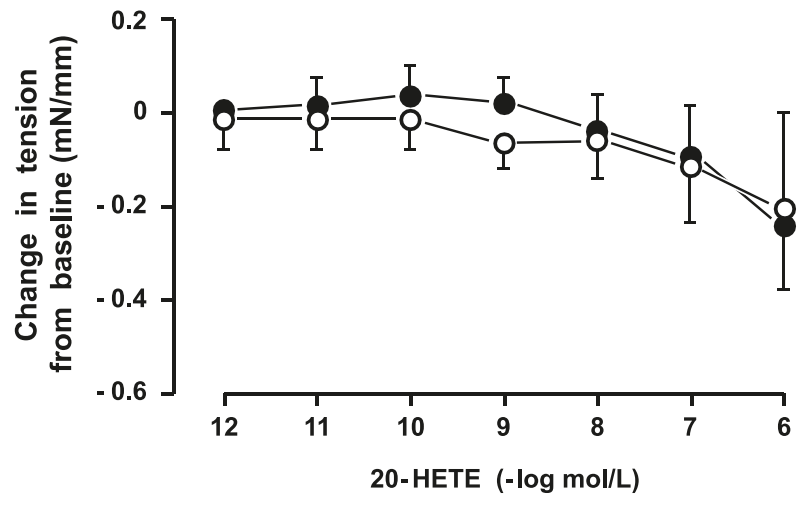

up in a dissection chamber containing ice-cold Krebs solution gassed with $5 \% \mathrm{CO}_{2}$ in $\mathrm{N}_{2}$. Through thoracotomy, the ductus was exposed, separated from adjoining blood vessels, and suspended onto $25 \mu \mathrm{m}$ tungsten wires (Cooner Wire Company, Chatsworth, N.J., USA) inside an organ bath. Fluid was gassed with a mixture containing $2.5 \% \mathrm{O}_{2}$, and the same gas mixture was flushed through a hood covering the bath. Preparations were then equilibrated (about $60 \mathrm{~min}$ at $37^{\circ} \mathrm{C}$ ) under minimal stretch (WT: $0.046 \pm 0.001 \mathrm{mN} / \mathrm{mm} ; n=38$ ) $\left(\right.$ Cyp3a $\left.{ }^{-1-}: 0.048 \pm 0.001 \mathrm{mN} / \mathrm{mm} ; n=3\right)$, and the attendant internal circumference $\left(C_{0}\right)$ with related resting dimension (WT: vessel length, long side: $567 \pm 13 \mu \mathrm{m}$; vessel length, short side: $554 \pm 13 \mu \mathrm{m}$; internal diameter: $134 \pm 1 \mu \mathrm{m}$; wall thickness: $20 \pm 0.3 \mu \mathrm{m} ; n=38)\left(\right.$ Cyp3a ${ }^{-1-}$ : vessel length, long side: $533 \pm 18 \mu \mathrm{m}$; vessel length, short side: $518 \pm 15 \mu \mathrm{m}$; internal diameter: $134 \pm 2 \mu \mathrm{m}$; wall thickness: $19 \pm 1 \mu \mathrm{m} ; n=3$ ) served as a reference for choosing the appropriate load. Afterwards, tension was applied to attain an operating circumference (i.e., $C_{50}$ ) coinciding with the condition in vivo (WT: $0.460 \pm 0.005 \mathrm{mN} / \mathrm{mm} ; n=38$ ) $($ Cyp3a-l: $0.460 \pm 0.009 \mathrm{mN} / \mathrm{mm} ; n=3)$. The actual experiment was started after a second equilibration of 60$120 \mathrm{~min}$.

The study comprised 2 groups of experiments dealing, respectively, with the action of inhibitors of AA epoxygenase and 12-lipoxygenase on oxygen-induced contraction and with the response of the ductus to 20-HETE. In group $1(n=35)$, oxygen action was examined over a range of concentrations $(12.5 \%, 30 \%, 95 \%)$ in the absence and presence of MS$\mathrm{PPOH}(5 \mu \mathrm{mol} / \mathrm{L})$, baicalein $(10 \mu \mathrm{mol} / \mathrm{L})$, or PD 146176 $(1 \mu \mathrm{mol} / \mathrm{L})$. Inhibitors were tested comparatively on the ductus contraction with ET-1 in view of the role being assigned to this compound as the ultimate effector in the oxygen activation sequence (Coceani 1999; Coceani et al. 1999; 
Fig. 3. Proposed scheme for arachidonic acid metabolism in the ductus arteriosus. Prostaglandin $\mathrm{E}_{2}$ is known to sustain prenatal patency, whereas a hitherto unidentified product from the combined action of 12(S)-lipoxygenase and epoxygenase is assigned a messenger role in the oxygen-induced postnatal closure.

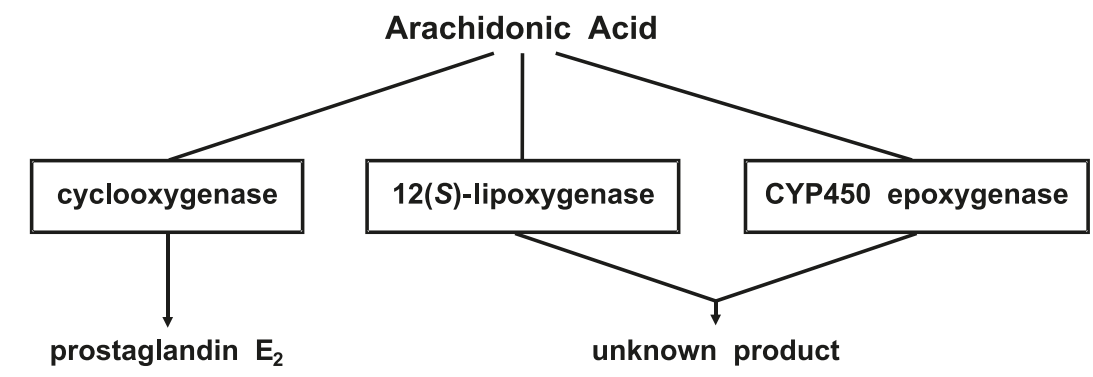

\section{DUCTUS RELAXATION}

Baragatti et al. 2011). ET-1 was applied to the organ bath in cumulative concentrations $(0.1-300 \mathrm{nmol} / \mathrm{L})$, using 3 - to 10-fold increments. In group $2(n=6), 20$-HETE action was studied comparatively in WT and Cyp $3 a^{-1-}$ preparations, expecting that for the sake of compensation a messenger function of the compound may be magnified in the mutant. 20-HETE was tested cumulatively in 10-fold increments $(1 \mathrm{pmol} / \mathrm{L}-1 \mu \mathrm{mol} / \mathrm{L})$. In either protocol, ONO-11113 $(0.1 \mu \mathrm{mol} / \mathrm{L})$ and, in some experiments, U-44069 $(0.3 \mu \mathrm{mol} / \mathrm{L})$ provided a reference for maximal contraction. For analysis of responses, baseline was taken as the net tension (i.e., total tension minus applied tension) developed by the preparation before any treatment. Any response to tests was measured by the change in tension relative to baseline and was expressed in absolute values.

\section{Statistical analysis}

Data are presented as means \pm SE. Comparisons were made using Student's $t$ tests or two-way ANOVA followed by the Bonferroni test (SPSS program for Windows 10; SPSS, Inc., Chicago, Ill., USA). Differences were considered significant at $p<0.05$.

\section{Results}

As previously reported (Baragatti et al. 2011), the WT ductus developed a variable degree of tension during equilibration at $2.5 \% \mathrm{O}_{2}(0.067 \pm 0.018 \mathrm{mN} / \mathrm{mm}, n=38)$ and, once stabilized, contracted to oxygen in a concentration-dependent manner (Figs. 1a, 1c). ET-1 was also a constrictor from about 0.1 to $30 \mathrm{nmol} / \mathrm{L}$, but the response in part subsided beyond that range (Figs. $1 b, 1 d)$. Transient contractions of uneven amplitude $(0.1-0.7 \mathrm{mN} / \mathrm{mm})$ and (or) low-amplitude discharges were often superimposed on the baseline and tended to increase during exposure to either agent. Unlike WT, the Cyp3a $a^{-/-}$ductus developed little or no tone at rest (see Baragatti et al. 2011), but its baseline still presented fast activity in 2 of 3 experiments. All preparations, whether WT or Cyp3a-l-, contracted to reference spasmogens ONO-11113 (0.1 $\mu \mathrm{mol} / \mathrm{L}$; WT: $1.08 \pm 0.07 \mathrm{mN} / \mathrm{mm}$; $n=12)$ and U-44069 (0.3 $\mu \mathrm{mol} / \mathrm{L} ; \mathrm{WT}: 0.86 \pm 0.09$; Cyp3a-- $1.00 \pm 0.04 \mathrm{mN} / \mathrm{mm} ; n=3$ for both).

The AA epoxygenase inhibitor MS-PPOH $(5 \mu \mathrm{mol} / \mathrm{L})$ had no effect on basal tension, but completely inhibited the tonic contraction to oxygen over its entire range of concentrations
DUCTUS CONSTRICTION

(Fig. 1a). In fact, the contraction was replaced by a relaxation in 2 experiments and, moreover, in one of them the response was concentration dependent. However, transient changes in tension, whether slow or fast in character, persisted throughout treatment. Contrary to its effect on oxygen, MS-PPOH did not alter the contractile response to either ET-1 (Fig. 1b) or ONO-11113 (1.01 $\pm 0.08 \mathrm{mN} / \mathrm{mm} ; n=7)$.

The AA 12-lipoxygenase inhibitors baicalein $(10 \mu \mathrm{mol} / \mathrm{L})$ and PD $146176(1 \mu \mathrm{mol} / \mathrm{L})$ contracted the resting ductus in all cases (baicalein: $0.43 \pm 0.07 \mathrm{mN} / \mathrm{mm}, n=8$; PD 146176: $0.31 \pm 0.05 \mathrm{mN} / \mathrm{mm}, n=4)$. No further increase in tone occurred in baicalein-treated preparations upon exposure to oxygen but, on the contrary, the original contraction was replaced by a concentration-dependent relaxation (Fig. 1c). Also curtailed was the oxygen response during treatment with PD 146176, although to a lesser degree compared with the response to baicalein (Fig. 1c). Conversely, ET-1 action was not affected by baicalein, the modest shift rightward of the concentration-response curve being insignificant (Fig. 1d). Likewise, ONO-11113 elicited a full-fledged contraction in the presence of either inhibitor (baicalein: $1.02 \pm 0.05 \mathrm{mN} /$ $\mathrm{mm}, n=8$; PD 146176: $0.85 \pm 0.19 \mathrm{mN} / \mathrm{mm}, n=4)$.

At variance with findings in the systemic circulation $(\mathrm{Ku}-$ nert et al. 2001), 20-HETE did not contract the ductus but instead produced a modest relaxation (Fig. 2). No difference in the pattern of the response was noted between WT and Cyp3a-l- preparations (Fig. 2).

\section{Discussion}

Our study accords with the concept of a CYP450 hemoprotein serving as sensor in the ductus constriction to oxygen and, moreover, links its operation with an AA-based epoxygenase reaction. Critical to our conclusion is the outcome of tests with MS-PPOH. In fact, by curtailing the tonic but not the phasic component of the oxygen response, this inhibitor mimicked in full the behaviour of the ductus lacking the sensor hemoprotein (i.e., CYP3A13; see Baragatti et al. 2011). Furthermore, considering the specificity of MS-PPOH as AA epoxygenase inhibitor (Wang et al. 1998), the same data argue against any involvement of a CYP450-based, AA $\omega$ hydroxylation reaction. This assumption is also strengthened by the negative results with 20-HETE, which according to current knowledge would be the prime candidate as oxygen mediator among the hydroxylation products (Kunert et al. 
2001). Quite unexpectedly, it was also found that the oxygen response is curtailed by treatment with a 12-lipoxygenase inhibitor. This finding, while providing a possible meaning to the marked upregulation of this enzyme in the neonatal ductus (Costa et al. 2006), raises the prospect of the putative oxygen messenger originating from the combined activity of AA epoxygenase and 12-lipoxygenase pathways. Our discussion will address this possibility.

Among AA lipoxygenases, 12-lipoxygenase is in principle well suited to a messenger role. Several data, for example, implicate this pathway in synaptic function (DeCostanzo et al. 2010). In addition, the initial metabolite (i.e., hydroperoxy product) in this and the allied 15-lipoxygenase pathways yields diverse active products (Pace-Asciak et al. 1999; Chawengsub et al. 2009). Significantly, this transformation may require the presence of a CYP450 hemoprotein, operating though as a hydroperoxide isomerase rather than an epoxygenase (Chawengsub et al. 2009). Hence, given the great potential of the eicosanoid system, it is not too far-fetched to think that the putative oxygen messenger may derive from the concerted operation of 2 distinct AA pathways. But what is the actual evidence in support of this concept? So far, 2 facts may be brought to bear. It has been shown that 12-HETE, with either " $R$ " or " $S$ " configuration, may serve as a substrate for epoxygenase (Jajoo et al. 1992; J.R. Falck, personal communication). Furthermore, CYP3A hemoproteins, which are not regarded as prime catalytic elements for fatty acid epoxidation, are still able to function as an AA epoxygenase (Ayajiki et al. 2003). Future work will build on this information while attempting to characterize the hypothetical messenger. In the meantime, it should be pointed out that a positive outcome from this search would reassert the central position of the eicosanoid system in ductus regulation, with the relaxant $\mathrm{PGE}_{2}$ prevailing prenatally and an epoxygenase-lipoxygenase product taking over postnatally (Fig. 3).

A final point deserves a comment relating to the nature of the contractile effect of baicalein and PD 146176 on the ductus. An unspecific phenomenon, being related to the known antioxidant action of baicalein, can be ruled out, since this particular property is not shared by PD 146176 (Sendobry et al. 1997). More likely, the response results from some interference with $\mathrm{PGE}_{2}$ function, which both inhibitors have in common (Sendobry et al. 1997; Woo et al. 2006).

In conclusion, our study marks a significant step forward in the knowledge of oxygen sensing in the ductus. The identity of the postulated CYP3A13 (sensor) to ET-1 (effector) messenger remains undefined. However, valuable information has been obtained on its possible mechanism of synthesis that should provide guidance towards the ultimate characterization.

\section{Acknowledgements}

This work was supported by a grant of the Italian Ministry of Education and Research (PRIN 2007E7Y7R).

\section{References}

Ayajiki, K., Fujioka, H., Toda, N., Okada, S., Minamiyama, Y., Imaoka, S., et al. 2003. Mediation of arachidonic acid metabolite (s) produced by endothelial cytochrome P-450 3A4 in monkey arterial relaxation. Hypertens. Res. 26(3): 237-243. doi:10.1291/ hypres.26.237. PMID:12675279.

Baragatti, B., Schwartzman, M.L., Angeloni, D., Scebba, F., Ciofini,
E., Sodini, D., et al. 2009. EDHF function in the ductus arteriosus: evidence against involvement of epoxyeicosatrienoic acids and 12S-hydroxyeicosatetraenoic acid. Am. J. Physiol. Heart Circ. Physiol. 297(6): H2161-H2168. doi:10.1152/ajpheart.00576. 2009. PMID:19801493.

Baragatti, B., Ciofini, E., Scebba, F., Angeloni, D., Sodini, D., Luin, S., et al. 2011. Cytochrome P-450 3A13 and endothelin jointly mediate ductus arteriosus constriction to oxygen in mice. Am. J. Physiol. Heart Circ. Physiol. 300(3): H892-H901. doi:10.1152/ ajpheart.00907.2010. PMID:21193583.

Chawengsub, Y., Gauthier, K.M., Nithipatikom, K., Hammock, B.D., Falck, J.R., Narsimhaswamy, D., and Campbell, W.B. 2009. Identification of 13-hydroxy-14,15-epoxyeicosatrienoic acid as an acid-stable endothelium-derived hyperpolarizing factor in rabbit arteries. J. Biol. Chem. 284(45): 31280-31290. doi:10.1074/jbc. M109.025627. PMID:19737933.

Chen, J.-K., Chen, J., Imig, J.D., Wei, S., Hachey, D.L., Guthi, J.S., et al. 2008. Identification of novel endogenous cytochrome P450 arachidonate metabolites with high affinity for cannabinoids receptors. J. Biol. Chem. 283(36): 24514-24524. doi:10.1074/ jbc.M709873200. PMID:18606824.

Coceani, F. 1999. Cytochrome P450 in the contractile tone of the ductus arteriosus. In The fetal and neonatal pulmonary circulations. Edited by E.K. Weir, S.L. Archer, and J.T. Reeves. Futura, Armonk, N.Y. pp. 331-341.

Coceani, F., and Kelsey, L. 2000. Endothelin-1 release from the lamb ductus arteriosus: Are carbon monoxide and nitric oxide regulatory agents? Life Sci. 66(26): 2613-2623. doi:10.1016/ S0024-3205(00)00595-6. PMID:10883739.

Coceani, F., Breen, C.A., Lees, J.G., Falck, J.R., and Olley, P.M. 1988. Further evidence implicating a cytochrome P-450-mediated reaction in the contractile tension of the lamb ductus arteriosus. Circ. Res. 62(3): 471-477. PMID:3124973.

Coceani, F., Liu, Y.A., Seidlitz, E., Kelsey, L., Kuwaki, T., Ackerley, C., and Yanagisawa, M. 1999. Endothelin A receptor is necessary for $\mathrm{O}_{2}$ constriction but not closure of ductus arteriosus. Am. J. Physiol. Heart Circ. Physiol. 277(4 Pt. 2): H1521-H1531.

Costa, M., Barogi, S., Socci, N.D., Angeloni, D., Maffei, M., Baragatti, B., et al. 2006. Gene expression in ductus arteriosus and aorta: comparison of birth and oxygen effects. Physiol. Genomics, 25(2): 250-262. doi:10.1152/physiolgenomics.00231.2005. PMID:16418320.

DeCostanzo, A.J., Voloshyna, I., Rosen, Z.B., Feinmark, S.J., and Siegelbaum, S.A. 2010. 12-Lipoxygenase regulates hippocampal long-term potentiation by modulating L-type $\mathrm{Ca}^{2+}$ channels. J. Neurosci. 30(5): 1822-1831. doi:10.1523/JNEUROSCI.2168-09. 2010. PMID:20130191.

Fay, F.S. 1973. Biochemical basis for response of ductus arteriosus to oxygen. In Fetal and neonatal physiology. Edited by K.S. Comline, K.W. Cross, G.S. Dawes, and P.W. Nathanielsz. Cambridge University Press, New York. pp. 136-140.

Jajoo, H.K., Capdevila, J.H., Falck, J.R., Bhatt, R.K., and Blair, I.A. 1992. Metabolism of 12(R)-hydroxyeicosatetraenoic acid by rat liver microsomes. Biochim. Biophys. Acta, 1123(1): 110-116. PMID:1730042.

Johannesson, M., Backman, L., Claesson, H.-E., and Forsell, P.K.A. 2010. Cloning, purification and characterization of non-human primate 12/15-lipoxygenases. Prostaglandins Leukot. Essent. Fatty Acids, 82(2-3): 121-129. doi:10.1016/j.plefa.2009.11.006. PMID: 20106647.

Kunert, M.P., Roman, R.J., Alonso-Galicia, M., Falck, J.R., and Lombard, J.H. 2001. Cytochrome P-450 $\omega$-hydroxylase: a potential $\mathrm{O}_{2}$ sensor in rat arterioles and skeletal muscle cells. 
Am. J. Physiol. Heart Circ. Physiol. 280(4): H1840-H1845. PMID:11247799.

Pace-Asciak, C.R., Reynaud, D., Demin, P., and Nigam, S. 1999. The hepoxilins: a review. Adv. Exp. Med. Biol. 447: 123-132. PMID: 10086189.

Reese, J., O'Mara, P.W., Poole, S.D., Brown, N., Tolentino, C., Eckman, D.M., and Aschner, J.L. 2009. Regulation of the fetal mouse ductus arteriosus is dependent on interaction of nitric oxide and COX enzymes in the ductal wall. Prostaglandins Other Lipid Mediat. 88(3-4): 89-96. doi:10.1016/j.prostaglandins.2008.11. 001. PMID:19049898.

Sendobry, S.M., Cornicelli, J.A., Welch, K., Bocan, T., Tait, B., Trivedi, B.K., et al. 1997. Attenuation of diet-induced atherosclerosis in rabbits with a highly selective 15-lipoxygenase inhibitor lacking significant antioxidant properties. Br. J. Pharmacol. 120(7): 1199-1206. doi:10.1038/sj.bjp.0701007. PMID: 9105693.
Smith, G.C.S. 1998. The pharmacology of the ductus arteriosus. Pharmacol. Rev. 50(1): 35-58. PMID:9549757.

van Herwaarden, A.E., Wagenaar, E., van der Kruijssen, C.M.M., van Waterschoot, R.A.B., Smit, J.W., Song, J.-Y., et al. 2007. Knockout of cytochrome P450 3A yields new mouse models for understanding xenobiotic metabolism. J. Clin. Invest. 117(11): 3583-3592. doi:10.1172/JCI33435. PMID:17975676.

Wang, M.-H., Brand-Schieber, E., Zand, B.A., Nguyen, X., Falck, J. R., Balu, N., and Schwartzman, M.L. 1998. Cytochrome P450derived arachidonic acid metabolism in the rat kidney: characterization of selective inhibitors. J. Pharmacol. Exp. Ther. 284(3): 966-973. PMID:9495856.

Woo, K.J., Lim, J.H., Suh, S.-I., Kwon, Y.-K., Shin, S.-W., Kim, S.-C., et al. 2006. Differential inhibitory effects of baicalein and baicalin on LPS-induced cyclooxygenase- 2 expression through inhibition of C/EBP $\beta$ DNA-binding activity. Immunobiology, 211(5): 359-368. doi:10.1016/j.imbio.2006.02.002. PMID:16716805. 